\title{
Fulminant hepatic failure in a patient with advanced extragonadal germ cell tumour
}

\author{
Alison Young, ${ }^{1}$ Ayman Madi, ${ }^{2}$ Darren Treanor, ${ }^{3}$ Charles Millson, ${ }^{4}$ Peter Selby, ${ }^{1}$ John Chester ${ }^{1}$ \\ ${ }^{1}$ Department of Medical Oncology, St James's Institute of Oncology, Leeds, UK \\ ${ }^{2}$ Department of Medical Oncology, Northern Centre for Cancer Care, Newcastle upon Tyne, UK \\ ${ }^{3}$ Department of Histopathology, St James's Institute of Oncology, Leeds, UK \\ ${ }^{4}$ Liver Unit, St James's University Hospital, Leeds, UK \\ Correspondence to John Chester, j.d.chester@leeds.ac.uk
}

\section{Summary}

Fulminant hepatic failure (FHF) in association with metastatic cancer, without evidence of liver metastases, has not been previously reported in the literature. This report concerns a case of FHF in a 36-year-old man with advanced germ cell tumour arising from an extragonadal (retroperitoneal) primary. Liver function and encephalopathy improved following chemotherapy, suggesting prompt diagnosis and treatment may have cured the patient. Following completion of chemotherapy, he developed spontaneous bacterial endocarditis, requiring aortic valve replacement, a rare complication of curative chemotherapy. At 44 months post completion of chemotherapy, he has regained his premorbid performance status and has returned to work.

\section{BACKGROUND}

Fulminant hepatic failure (FHF) is defined as hepatic failure complicated by encephalopathy occurring within 8 weeks of the onset of the underlying illness in the absence of any known pre-existing liver disease. The commonest causes of FHF are viral or drug-induced hepatitis, although aetiology remains unknown in a significant proportion of patients. ${ }^{12}$ Survival rates of FHF in patients who are not suitable for liver transplantation, as in this patient, are as low as $15 \%{ }^{3}$ FHF in association with metastatic cancer with no evidence of radiologically (or histologically) detectable liver metastases has not been reported previously.

\section{CASE PRESENTATION}

A 36-year-old man, on no regular medications, with no history of chronic liver disease, illicit drug use or excess alcohol intake and no testicular maldescent, presented to his local hospital with a swollen right leg following a simple fall. An ultrasound scan showed a deep vein thrombosis and a large retroperitoneal mass. He was given low molecular weight heparin, a biopsy of the retroperitoneal mass was carried out and following this he was given warfarin. Histology was consistent with classical seminoma.

Liver function tests at presentation were normal, apart from an elevated lactate dehydrogenase level at 3025 IU/1 (normal range 210-570 IU/litre). Blood tumour markers showed mildly elevated human choriogonadotrophin (HCG) at $57 \mathrm{U} /$ litre (normal $<5 \mathrm{U} /$ litre) and normal -fetoprotein (AFP) at $1 \mathrm{kU} /$ litre (normal $<10 \mathrm{kU} /$ litre). Then, 3 weeks later, he was seen in the regional specialist germ cell clinic, by which time he was tachycardic, tachypnoeic and jaundiced, with no evidence of encephalopathy. A physical examination revealed a distended abdomen with a large palpable solid mass. The testes were atrophic. Liver function tests were grossly abnormal and tumour markers showed a mildly elevated HCG level with normal AFP (see table 1). The international normalised ratio (INR) was not used as an indicator of liver function as the patient was on warfarin. The patient was admitted from the clinic for assessment of his rapid decline and consideration of urgent chemotherapy. A baseline CT scan showed a large retroperitoneal mass with no other obvious abnormality (figure 1), specifically there was no evidence of liver metastases or renal tract compromise.

\section{Treatment}

Within $24 \mathrm{~h}$ of admission, he received chemotherapy with single-agent carboplatin as he was felt to be too unwell for standard bleomycin, etoposide and cisplatin chemotherapy. Bleomycin was felt to be inappropriate in view of his breathlessness and etoposide due to his deranged liver function. Later the same day, he became more unwell with grade II encephalopathy and a reduced conscious level. He subsequently became unconscious with a decorticate position, was intubated and transferred to the intensive care unit (ICU). A CT scan and MRI scan of the brain, electroencephalograph and a lumbar puncture were all unremarkable, excluding any obvious neurological cause for the rapid deterioration in his conscious level. In view of his severely deranged liver function, he was managed as a case of hepatic failure with the help of the specialist liver team. There was no serological evidence of hepatitis B/C infection or recent infection with hepatitis $\mathrm{A} / \mathrm{E}$ viruses, cytomegalovirus or Epstein-Barr virus. Autoantibody and antineutrophil cytoplasmic antibody screens were negative. -1-Antitrypsin and ceruloplasmin levels were also normal and there was nothing to suggest a recent paracetamol overdose. A transjugular biopsy of the liver was carried out. Histopathological examination of this confirmed confluent zonal and panacinar necrosis without specific aetiological features; in particular there was no evidence of malignancy in the random biopsy (figure 2). 


\section{BMJ Case Reports}

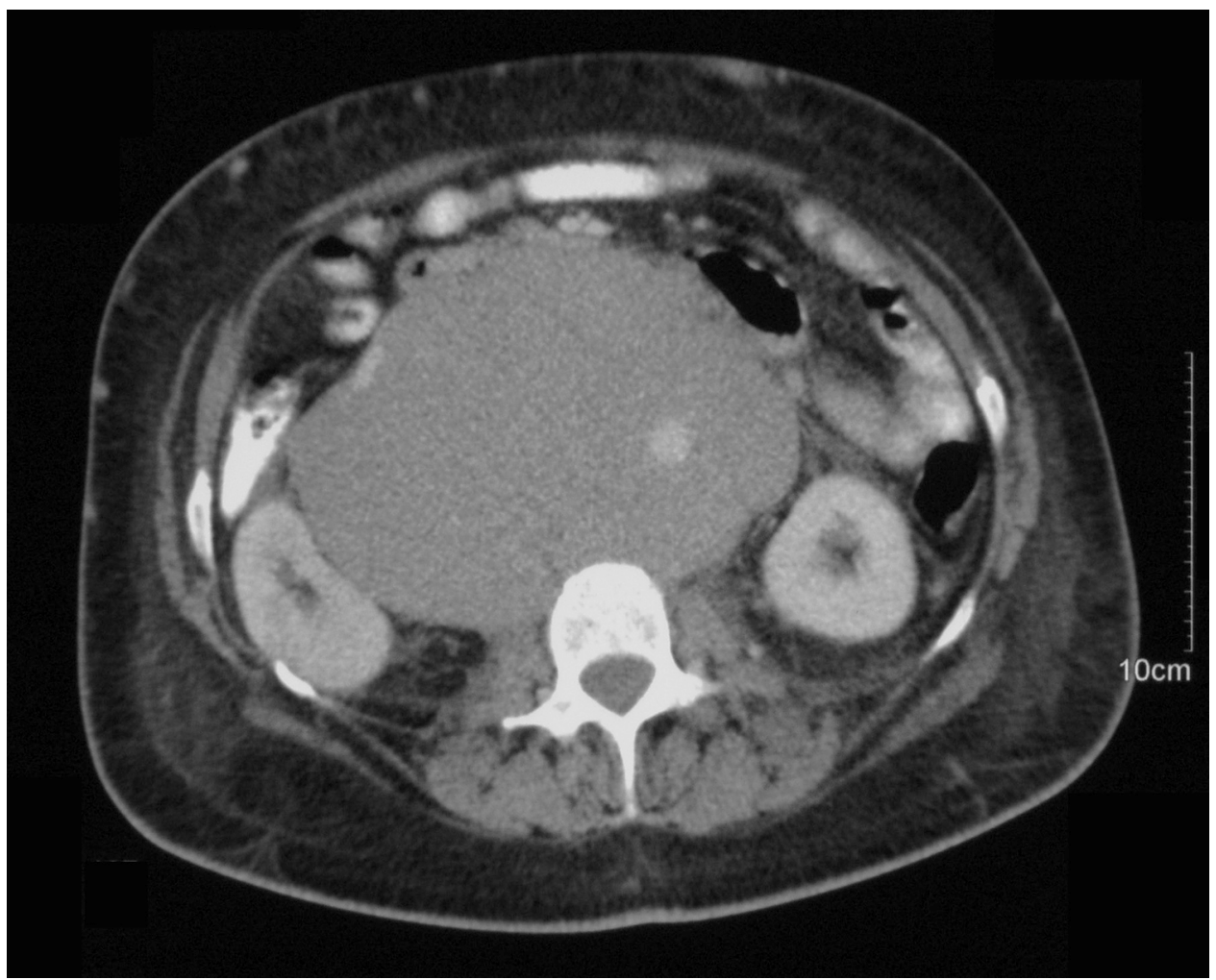

Figure 1 CT image showing the large retroperitoneal mass.

His clinical condition and liver enzymes started to improve following his first dose of carboplatin chemotherapy (table 1). After 2 weeks in the ICU, he was transferred to the liver unit and his clinical condition and liver enzymes continued to improve. A reassessment CT scan, approximately 3 weeks after his first cycle of chemotherapy, showed a partial response, with reduction of the retroperitoneal mass from $17 \times 13$ to $9 \times 4 \mathrm{~cm}$. He received a second dose of carboplatin at AUC4 4 weeks after his firstdose and tolerated this well.

Table 1 Blood results showing improvement of liver function as chemotherapy treatment progressed

\begin{tabular}{|c|c|c|c|c|c|c|c|c|}
\hline \multirow[t]{2}{*}{ Blood test } & \multicolumn{8}{|c|}{ Time line, weeks } \\
\hline & -4 & -3 & $\begin{array}{l}0 \text { (first chemotherapy) } \\
\text { carbo (AUC4) }\end{array}$ & $\begin{array}{l}+4 \text { (second chemo- } \\
\text { therapy) carbo (AUC4) }\end{array}$ & $\begin{array}{l}+7 \text { (third } \\
\text { chemotherapy) EP }\end{array}$ & $\begin{array}{l}+10 \text { (fourth } \\
\text { chemotherapy) EP }\end{array}$ & $\begin{array}{l}+13 \text { (fifth } \\
\text { chemotherapy) EP }\end{array}$ & +15 \\
\hline $\mathrm{Hb}$ & & 11.4 & 14.3 & 9.2 & 11.0 & 10.3 & 9.3 & \\
\hline WCC & & 5.1 & 8.0 & 3.52 & 6.42 & 11.42 & 5.70 & \\
\hline Neutrophils & & & 7.01 & 2.85 & 5.70 & 9.85 & 4.23 & \\
\hline Platelets & & 183 & 106 & 64 & 95 & 106 & 106 & \\
\hline INR & & 3.0 & 10.1 & 1.1 & & & & \\
\hline Bilirubin & 9 & & 81 & 256 & 75 & 35 & 13 & \\
\hline ALT & 115 & & 3344 & 151 & 91 & 41 & 26 & \\
\hline ALP & 214 & & 1278 & 447 & 497 & 626 & 306 & \\
\hline Albumin & & & 42 & 29 & 32 & 30 & 29 & \\
\hline LDH & & & 7606 & & 471 & & & 393 \\
\hline AFP & & & 7 & & 4 & 4 & & 7 \\
\hline HCG & & & 39.9 & & 11.3 & $<2$ & & $<2$ \\
\hline
\end{tabular}

EP, Cisplatin and Etopiside Chemotherapy; AFP, -fetoprotein; ALP, alkaline phosphatase; ALT, alanine aminotransferase; AUC, area under the curve; carbo, carboplatin; $\mathrm{Hb}$, haemoglobin; HCG, human chorionic gonadotrophin; INR, international normalised ratio; LDH, lactate dehydrogenase; WCC, white cell count. 

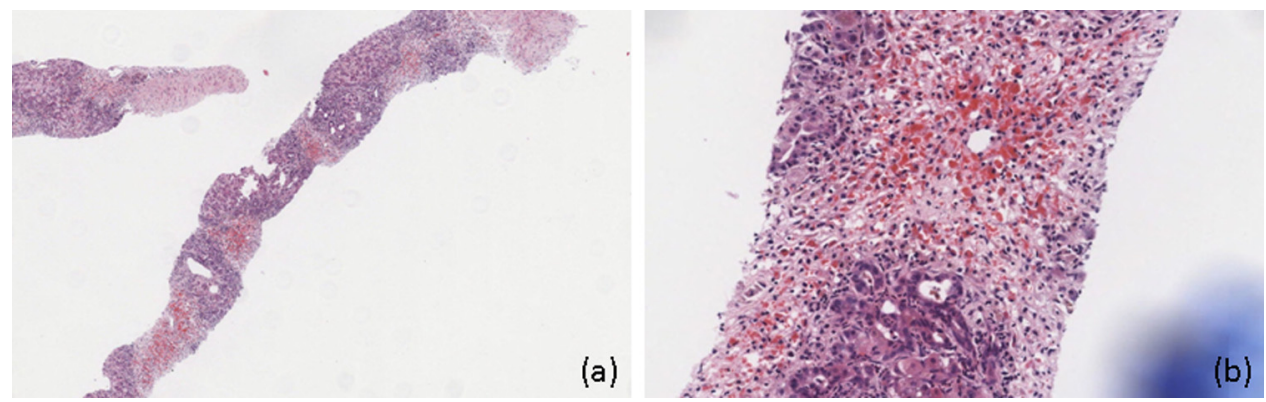

Figure 2 A. Liver biopsy (H\&E stain, 20× magnification) showing confluent zonal and panacinar necrosis, with replacement of the parenchyma by areas of haemorrhage. The biopsy has a variegated appearance due to the interposition of haemorrhage (red/pink) and remaining parenchyma (purple) (H\&E stain, 10×). B. High power view of one affected area shows only a few remaining hepatocytes (top left and bottom), with a large area of haemorrhage replacing the parenchyma. Reactive bile ductular proliferation and cholangiolitis is present in the portal tract at the bottom of the figure: features often seen in areas adjacent to liver cell necrosis. There was no evidence of malignancy in the biopsy specimen.

After further dramatic improvement in his clinical condition he received three further cycles of chemotherapy with etoposide and cisplatin, given at 3-weekly intervals from 7 weeks after his first dose of carboplatin. The cisplatin was given at full dose $\left(100 \mathrm{mg} / \mathrm{m}^{2}\right.$ per cycle), but a reduction in the etoposide dose of two-thirds was used in view of his persisting liver impairment. A post chemotherapy CT scan showed a further reduction in the retroperitoneal mass to $4 \times 2.5 \mathrm{~cm}$.

He remained an inpatient throughout his chemotherapy, requiring continuous physiotherapy and occupational therapy input. He was discharged 2 weeks after his final cycle of chemotherapy. At 4 days after discharge, he became unwell and was readmitted with fever. Vegetations were seen on the aortic valve on transthoracic echocardiography and blood cultures grew Enterococci. A diagnosis of bacterial endocarditis was made and approximately 4 weeks after his final cycle of chemotherapy, he underwent an emergency aortic valve replacement with mitral valve debridement and insertion of a metal prosthetic valve. He also required insertion of a pacing device in view of an episode of complete heart block. He recovered well and was discharged a month later.

\section{OUTCOME AND FOLLOW-UP}

When last reviewed in the outpatient clinic, 44 months after commencing chemotherapy, he was well and had returned back to work. There were no signs or symptoms of hypoxic or neurological damage and no evidence of disease recurrence on a CT scan. Liver function tests were normal at this time.

\section{DISCUSSION}

FHF has been seen and reported in metastatic malignancy where there is malignant infiltration of the liver, ${ }^{4}$ but this is the first report to describe an association between (germ cell) tumour and FHF, with no evidence of hepatic metastases or any other identifiable cause. A potential suggestion for the cause of FHF in this case is paraneoplastic cholestasis. Cholestasis in cancer patients can be due to a number of causes including mechanical obstruction by the primary tumour, external compression due to tumour bulk, or due to metastatic involvement of the liver. However in a small number of patients, when the above causes have been excluded, the cholestasis has been attributed to a paraneoplastic syndrome and reports of this have been seen in prostate $^{5}$ and renal cancer patients. ${ }^{6}$

It is impossible to be certain of the cause of endocarditis in this case, but central venous catheters can lead to an increase in the incidence of endocarditis. ${ }^{7}$ It seems likely that, in this case, endocarditis was related to the combination of a central venous catheter during his stay in the ICU plus the use of immunosuppressive chemotherapy.

This case also reiterates the potentially life-saving importance of using chemotherapy in patients with potentially curable tumours responsive to chemotherapy, even when the patient is critically ill, and the value of a multidisciplinary team in a specialist cancer centre in achieving a cure for such patients. This particular case involved the input of medical oncologists, intensive care specialists, hepatologists, neurologists, cardiothoracic surgeons and a rehabilitation team, each of which provided essential input in their specialist area.

\section{Learning points}

- Fulminant hepatic failure (FHF) can occur in association with metastatic cancer with no evidence of metastatic infiltration of the liver.

- The use of curative chemotherapy for patients who are critically ill with germ cell tumours responsive to chemotherapy is important in trying to achieve a cure.

- Working within a large multidisciplinary team improves patient outcomes.

\section{Competing interests None.}

Patient consent Obtained.

\section{REFERENCES}

1. Lee WM. Acute liver failure N Engl J Med 1993:329:1862-72

2. O'Grady JG. Acute liver failure. Postgrad Med J 2005;81:148-54

3. Gotthardt D, Riediger C, Weiss KH, et al. Fulminant hepatic failure: etiology and indications for liver transplantation. Nephrol Dial Transplant 2007;22:viiï-viiï. 


\section{BMJ Case Reports}

4. Kaira K, Takise A, Watanabe R, et al. Fulminant hepatic failure resulting from small-cell lung cancer and dramatic response of chemotherapy. World $\mathrm{J}$ Gastroenterol 2006;12:2466-8.

5. Koruk M, Bpypkberber M, Savas C, et al. Paraneoplastic cholestasis associated with prostate carcinoma. Turk J Gastroenterol 2004;15:53-5.

6. Morla D, Alazemi S, Lichtstein D. Stauffer's syndrome variant with cholestatic jaundice: a case report. J Gen Intern Med 2006;21:C11-13.
7. Hachem R, Raad I. Prevention and management of long-term catheter related infections in cancer patients. Cancer Invest 2002;20:1105-13.

8. Liepman MK, Jones PG, Kauffman CA. Endocarditis as a complication of indwelling right atrial catheters in leukemic patients. Cancer 1984:54:804-7.

This pdf has been created automatically from the final edited text and images.

Copyright 2010 BMJ Publishing Group. All rights reserved. For permission to reuse any of this content visit http://group.bmj.com/group/rights-licensing/permissions.

BMJ Case Report Fellows may re-use this article for personal use and teaching without any further permission.

Please cite this article as follows (you will need to access the article online to obtain the date of publication)

Young A, Madi A, Treanor D, Millson C, Selby P, Chester J. Fulminant hepatic failure in a patient with advanced extragonadal germ cell tumour. BMJ Case Reports 2010;10.1136/bcr.01.2010.2661, date of publication

Become a Fellow of BMJ Case Reports today and you can:

Submit as many cases as you like

Enjoy fast sympathetic peer review and rapid publication of accepted articles

Access all the published articles

- Re-use any of the published material for personal use and teaching without further permission

For information on Institutional Fellowships contact consortiasales@bmjgroup.com

Visit casereports.bmj.com for more articles like this and to become a Fellow 